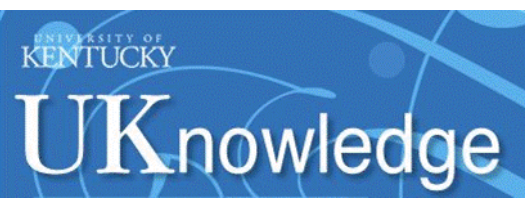

University of Kentucky

UKnowledge

$9-2014$

\title{
Assessing the Relationships Between Perceived Support From Close Others, Goal Commitment, and Persistence Decisions at the College Level
}

Renee E. Strom

Saint Cloud State University

Matthew W. Savage

University of Kentucky, matthewsavage@uky.edu

Follow this and additional works at: https://uknowledge.uky.edu/comm_facpub

Part of the Communication Commons

Right click to open a feedback form in a new tab to let us know how this document benefits you.

\section{Repository Citation}

Strom, Renee E. and Savage, Matthew W., "Assessing the Relationships Between Perceived Support From Close Others, Goal Commitment, and Persistence Decisions at the College Level" (2014). Communication Faculty Publications. 4.

https://uknowledge.uky.edu/comm_facpub/4

This Article is brought to you for free and open access by the Communication at UKnowledge. It has been accepted for inclusion in Communication Faculty Publications by an authorized administrator of UKnowledge. For more information, please contact UKnowledge@lsv.uky.edu. 


\section{Assessing the Relationships Between Perceived Support From Close Others, Goal Commitment, and Persistence Decisions at the College Level}

Digital Object Identifier (DOI)

http://dx.doi.org/10.1353/csd.2014.0064

Notes/Citation Information

Published in The Journal of College Student Development, v. 55, no. 6, p. 531-547.

Copyright @ 2014 The Johns Hopkins University Press. This article first appeared in The Journal of College Student Development, Volume 55, Issue 6, Sept., 2014, pages 531-547. 


\section{Assessing the Relationships Between Perceived Support From Close Others, Goal Commitment, and Persistence Decisions at the College Level}

\begin{abstract}
Renee E. Strom Matthew W. Savage
Research on supportive communication was examined in relation to students' goals of earning a college degree and their intent to persist. Theories of student departure (Bean, 1985; Tinto, 1993) informed research questions assessing the impact of how social support from family members and friends affected commitment to the goal of graduation and how commitment to the goal of graduation influenced intent to persist. First-year college students completed a questionnaire at 2 time points during their first year of college. Results revealed that initial support from family and friends positively impacted initial commitment to the goal of graduation. Subsequent support from family impacted subsequent commitment to the goal of graduating, and subsequent commitment to graduating impacted intention to persist.
\end{abstract}

First-year college students enter with a variety of high school academic experiences, exposure to college information, and family socioeconomic and educational influences, all of which help shape expectations and attitudes of what it is like to be a successful college student (Cole, Kennedy, \& Ben-Avie, 2009). Research reveals that $49 \%$ of students who began postsecondary education in 2003-2004 earned a credential by June 2009; another $15 \%$ remained enrolled, but had not yet completed a program of study; and 36\% left postsecondary education without a credential of any kind by June of 2009 (Radford, Berkner, Wheeless, \& Shepard, 2010). Renewed interest in the college student departure puzzle (e.g., Braxton, 2000) is evidence for a reexamination of several communication variables that may predict student persistence.

Researchers have noted the importance of examining first-year students' transition to college, as this is a critical predictor of their future academic achievement when students face particularly unique stressors (DeBerard, Spielmans, \& Julka, 2004; Lafreniere \& Ledgerwood, 1997). Of the 2.2 million students attending US universities, between $25 \%$ and $30 \%$ do not return to their initial institution for the second year. Scholars have noted that the greatest loss occurs during the first year, especially during the first semester (Rausch \& Hamilton, 2006). The stressors these new college students encounter are coupled with their separation from familiar sources of support from family and friends (Lafreniere \& Ledgerwood, 1997; MacGeorge, Samter, \& Gillihan, 2005), yet the contributions of familiar sources of social support are not specifically delineated in models of student persistence. Research has revealed that students' ability to persist in higher education until degree completion is affected by their commitment to the goal of graduation (Braxton \& McClendon, 2002; Pascarella \& Terenzini, 1991), but support

Renee E. Strom is Associate Professor of Communication Studies at Saint Cloud State University. Matthew W. Savage is Assistant Professor at the University of Kentucky. This research was funded by the Mannoa Undergraduate Experience and Engagement Committee, an initiative of the University of Hawai'i at Mānoa Office of Undergraduate Education to improve undergraduate student retention. 
students perceive having from important close others has not been considered in the constellation of student entry characteristics that may affect persistence decisions. We examined the impact of initial and subsequent support from first-year students' family and friends on their commitment to the goal of college graduation, and subsequently how their goal commitment affected intent to persist in college.

\section{MODELS OF STUDENT PERSISTENCE}

Student persistence refers to the desire and action of a student to voluntarily stay within the system of higher education from beginning year through degree completion (Berger \& Lyon, 2005). Although college student departure has been examined from different perspectives, two models in particular provide a comprehensive explanation of college student persistence decisions (Braxton, Millem, \& Sullivan, 2000): Tinto's interactionalist theory of student departure $(1975,1987,1993)$ and Bean's student attrition model (1980, 1982, 1983, 1985). Few scholars have attempted to amalgamate these two perspectives, but in line with past scholarship by Cabrera, Castaneda, Nora, and Hengstler (1992) and Cabrera, Nora, and Castaneda (1993), strengths from each model might be combined to better explain students' persistence decisions.

In brief, Tinto's theoretical model (1993) describes a longitudinal process whereby student entry characteristics (e.g., students' precollege schooling experiences, like high school achievement; SES; parental educational attainment) impact initial commitment to the goal of graduation and initial commitment to the institution. In turn, these initial commitments are affected by students' academic and social integration, thus resulting in students' subsequent commitment to the goal of graduation and subsequent commitment to their institution. Students' entry characteristics, subsequent commitment to the goal of graduation, and subsequent commitment to their institution are all argued to affect students' persistence decisions. The term initial is used here to describe the commitments that students hold prior to interacting with their institution, whereas the term subsequent refers to the level of these commitments that students hold based on their interactions with the formal and informal systems of their institution.

A second model that has been put forth to explain student persistence is Bean's student attrition model (1980, 1982, 1983, 1985). The student attrition model has many similarities to Tinto's interactionalist model (Hossler, 1984), yet, the student attrition model more strongly emphasizes the role of factors external to the institution in affecting both attitudes and decisions related to students' persistence (Bean, 1982, 1983). Unlike Tinto's work, research on the student attrition model emphasizes the role of intention to persist, attitudes toward persistence, and external factors in the form of family approval of institutional choice, and friends' encouragement to continue enrollment (among other variables not pertinent to this study). These external factors provide a varying view of what affects student persistence decisions (Bean, 1982, 1983). In line with the underlying assumption of the student attrition model, it may be especially worthwhile to examine how external variables, like interpersonal social support, affect students' process of developing commitment to the goal of graduation.

\section{Perceived Support as Student Entry Characteristic}

Interpersonal support that is communicated may play a larger role in a student's commitment to the goal of graduation than 
previously noted in Tinto's and Bean's works. Cabrera et al. (1992) found that Bean's student attrition model is a better predictor of both intent to persist and persistence because it takes into account external factors like parental encouragement and support from friends. Communication scholars have studied the impact of how support is communicated in families (Cutrona, Cole, Colangelo, Assouline, $\&$ Russell, 1994) and friendships (Thompson, 2008) in a variety of contexts (e.g., health issues, personal struggles). Other researchers have found that the level of social support received predicts how well students adjust during the college transition (Kenny \& Rice, 1995; Lafreniere \& Ledgerwood, 1997) and that total, or global, level of social support was a significant independent predictor of academic achievement (Cutrona et al., 1994; DeBerard et al., 2004). Also, support from specific relationships can contribute to personal adjustment over and beyond the impact of global perceived support (Aseron, Sarason \& Sarason, 1992). To that end, understanding how specific types of support may differentially impact academic outcomes is important.

\section{Perceived Support From Close Others}

Perceived support from family has been investigated with a variety of outcomes. A burgeoning line of research suggests that social support provided by family serves to buffer against adverse mental health outcomes, and both personal and school maladjustment (Demaray \& Maleck, 2002). Research linking perceived support from family and academic outcomes has been found to influence students' academic performance and student learning in school (Banks, Slavings, \& Biddle, 1990; Cutrona et al., 1994; DeBerard et al., 2004; Mortenson, 2006) and decrease academic stress for students (MacGeorge et al., 2005). There is also some consistent evidence that low perceived social support is related to nonpersistence (Mallinckrodt \& Leong, 1992). Furthermore, meta-analyses have revealed strong relationships between shared parental expectations for children's educational achievement and subsequent high school achievement (Fan \& Chen, 2001) as well as high school completion (Strom \& Boster, 2007). Students' schooling expectations are learned over time and these findings reveal that family support does academically impact students. Yet, there is a dearth of research investigating how perceived support from family impacts academic decisions like persistence to college graduation.

Within Tinto's model $(1975,1987,1993)$ student entry characteristics include students' precollege schooling experiences, individual qualities, and family background. Precollege schooling experiences are characterized by students' high school achievement and individual descriptive qualities including demographic characteristics such as sex, age, and ethnicity. Also included in student entry characteristics are family background characteristics (e.g., parents' education level and family socioeconomic status). It is important to note that Tinto's model does not directly address support that students may have received from family nor expectations for school success (e.g., stressing the importance of getting a college degree). Further, support that family provides is only marginally accounted for in Bean's model. The main focus of both models is how the interactions within the institution affect persistence, rather than those interactions students experience outside of the institution (Cabrera et al., 1993).

Like family, friends may also offer support that is unaccounted for by other components in Tinto's model. Friendships are voluntary relationships wherein individuals are expected to provide emotional support, to volunteer assistance, to keep each other's confidences, 
and to stand up for each other (Argyle \& Henderson, 1984; Weinstock \& Bond, 2000). During young adulthood, friends influence each other's self-conception, recreational activities, career options, and even mate selection (Rawlins, 1992). Prior research has shown that the quality of relationships with peers impacts subjective well-being among college students. For example, loneliness among first-year college students was predicted by quality of relationships with friends but not by quality of relationships with parents (Cutrona, 1982). Work by Thompson (2008) reveals that student academic support during the first year of college influenced academic performance where students believed they learned material more effectively when they worked with other students outside of the classroom setting. Yet work by Cutrona et al., (1994) found that there was no effect of friend support on GPA in a sample of first-year and second-year college students. Thus, it is unclear how support from friends may impact a student's goal to graduate.

Work by Cabrera et al. (1993) to merge the aforementioned Tinto and Bean models of student persistence resulted in an integrated model where the environmental variables from Bean's (1985) model (initial encouragement from friends and family) did indirectly impact both goal commitment and intent to persist. Yet, subsequent support from close others is not included in either model. Research by Toor (2000) reveals that parents participate in the college choice process, but it is unclear to what extent and for how long. It is very possible that support from family and friends is just as important during the process of attending college as it is at the outset of college. For example, a student who is struggling with a class may rely heavily on support from close others to continue in the class and subsequently towards the goal of graduating. This may be especially true during the first semester or two of college when new friendships are still forming and reliance on already established forms of support from family and established friends may be higher. Thus, both initial and subsequent support should be assessed concerning students' commitment to the goal of graduation at the start of college and during their first year of college. To examine these relationships, the first two research questions are posited:

RQ1: To what degree will initial support from family and friends impact initial commitment to the goal of graduation?

RQ2: To what degree will subsequent support from family and friends impact subsequent commitment to the goal of graduation?

Just as students' entry characteristics are important to consider in terms of persistence, so are students' commitment to the goal of graduation. Although there are two simultaneous commitment processes within Tinto's (1993) model (commitment to the goal of graduation and institutional commitment), the former, also known as goal commitment, is addressed here. Initial student commitment to the goal of graduation refers to the extent to which students value an undergraduate degree at the time that they enter their college or university (Brower, 1992). Within Tinto's model of student persistence, the element of initial student commitment to the goal of graduation illustrates the commitment that students feel toward earning a college education. Subsequent student commitment to the goal of graduation refers to the extent to which students' value earning an undergraduate degree after they have attended a college or university. Tinto (1993) originally described this goal commitment in terms of students' disposition toward the academic dimensions of a college or university. Tinto claims that whether the individual decides to drop out is 
significantly affected in part by commitment to the goal of college completion. Tinto posited that integration into the academic system of college directly affects goal commitment. Yet, research incorporating goal commitment has revealed mixed results when testing the impact of this construct in quantitative models (e.g., for reviews see Pascarella \& Terenzini, 1991 and Wofford, Goodwin, \& Premack, 1992). Higher subsequent commitment to the goal of graduation has been shown to be positively correlated with student persistence (Pascarella \& Terenzini 1991, 1998; Pascarella, Terenzini, \& Wolfe, 1986; Terenzini, Pascarella, Theophilides, \& Lorang, 1985), while other studies have found that no relationship exists between subsequent commitment to the goal of graduation and student persistence (Brower, 1992; Perry, Cabrera, \& Vogt, 1999; Thomas, 2000). Further, meta-analyses conducted by Braxton, Sullivan, and Johnson (1997) and Braxton and Lee (2005) have not shown strong support that students' subsequent commitment to the goal of graduation is reliably related to persistence. Thus, it is unclear if goal commitment is predictive of intent to persist. In order to assess this relationship, the final research question is posited:

RQ3: To what degree will an individual's subsequent commitment to the goal of graduation predict intention to persist in college?

\section{METHOD}

\section{Participants}

A random sample of first-year traditional students was recruited from the 2007-2008 class of a midsized university in the Western US. Because of our focus on examining entry characteristics, the sampling strategy was to recruit incoming students who lacked previous experience in college or university systems and had completed high school at the end of the previous academic year. Participants who completed both data collections were 101 first-year traditional students (36 males and 65 females) ranging in age from 17-19 years $(M=17.74, S D=.46)$. Respondents reported being enrolled for 13.83 credits $(S D=1.99)$ on average for the Fall 2007 semester, 14.15 credits $(S D=2.08)$ for the Spring 2008 semester, and 14.23 credits $(S D=3.91)$ for the Fall 2008 semester. Respondents were culturally diverse, including White $(n=25$, $24.8 \%)$, Japanese $(n=18,17.8 \%)$, mixed without Hawaiian ( $n=15,14.9 \%)$, Hawaiian or part-Hawaiian $(n=12,11.9 \%)$, Chinese $(n=12,11.9 \%)$, Filipino $(n=10,9.9 \%)$, Korean $(n=4,4.0 \%)$, African American $(n=1,0.5 \%)$, and other ethnicities $(n=25$, $13 \%)$. A total of $81 \%$ of participants $(n=85)$ reported that their parents were together, while 19\% reported that their parents were divorced. Additionally, participants were asked to report on their living situation: $57 \%$ reported that they lived on campus (dorm or other on-campus housing), 7\% reported living at a residence within walking distance of the university, and 35\% reported living at a residence within driving distance of the university. Participants reported an average high school GPA of $3.50(S D=0.35)$.

\section{Procedures}

At the start of the 2007-2008 academic year a letter was sent to 400 randomly selected incoming first-year traditional students who had informed the university of their intent to accept their admission offer. The letter explained the study and invited them to volunteer for the study if they wished. Results of this study are based on two data collections: the first collection at Time $1\left(\mathrm{~T}_{1}\right)$ occurred one week prior to students' beginning classes in the Fall 2007 semester (i.e., the third week of August), and the second collection at Time 
$2\left(\mathrm{~T}_{2}\right)$ occurred at the end of the students' first year in college, the end of the Spring 2008 semester (i.e., the second week of May). Participants who responded were asked to report on their student entry characteristics ( $\mathrm{T}_{1}$ only), their initial commitment to the goal of graduation $\left(\mathrm{T}_{1}\right)$, their subsequent commitment to the goal of graduation $\left(\mathrm{T}_{2}\right)$, and their intention to persist in college ( $\mathrm{T}_{2}$ only). Participants reported on their perceptions of how their family and friends supported their goal to earn a college degree during both data collections $\left(\mathrm{T}_{1}\right.$ and $\left.\mathrm{T}_{2}\right)$. After completion of each of the $T_{1}$ and $T_{2}$ questionnaires, participants were invited to print off their proof-of-participation page and use it to redeem a $\$ 15$ gift card to Safeway supermarket as a token of appreciation for their participation.

\section{Instrumentation}

Student Entry Characteristics. A variety of student entry characteristics were assessed at $\mathrm{T}_{1}$ and were included as control variables in the subsequent analyses. High school GPA $(M=3.50, S D=.36)$, whether students were first-generation college students (dummy coded as $0=$ no, $1=$ yes; $M=.39, S D=.49$ ), and distance in miles living from campus $(M=1.23, S D=2.13)$ were included. Additionally, parental income / socioeconomic status was also included $(M=\$ 65,734$, Median $=\$ 60,000, S D=\$ 41,755)$. In order to understand the impact financial support may have on goal commitment, parents' financial contribution to college was also included as a control variable in the analysis with responses ranging from 1 (none or very little) to 4 (all or nearly all $),(M=2.80, S D=1.21)$. Most commonly, $43 \%$ of participants reported that their family would pay for all or nearly all of their college expenses, whereas $17 \%$ reported that more than half of expenses would be paid by family, 19\% reported that less than half would be paid, and $21 \%$ reported that none or very little would be paid by family. Participants reported the highest education achieved (some high school, high school diploma, some college, 4-year college degree, graduate degree) for their mothers $(M=3.21, S D=1.24)$ and fathers $(M=3.19, S D=1.23)$.

Open-Ended Descriptive Responses. Participants were asked to describe in an open-ended response how they heard about the university. Two undergraduate research assistants were trained to code each response according to a coding scheme developed by the primary researcher. All responses were coded into one of the following categories: family, friends, college fair, high school counselor, mass media, I live here, and other. Cohen's kappa was used to assess coder reliability, or the proportion of agreement between raters after accounting for chance (Cohen, 1960), $\kappa=0.71$. Coders discussed discrepant codes to develop a consensus decision. Of the respondents, $27 \%$ said they heard about the university from family, 32\% reported they live here, $12 \%$ said they heard about the university through the mass media (flyer, internet), 9\% said from friends, and $9 \%$ reported other sources. Examples of responses that noted hearing about the university from family and friends are "My brother and father both attended and graduated from this school and they told me how great it is," "My parents talk about school and this school in particular all the time," and "My friends and I always talked about going here."

Participants also reported descriptive information about how they came to the decision to attend the university. Two undergraduate research assistants were trained to code each response according to a coding scheme developed by the primary researcher, $\kappa=.69$. All responses were coded into the following categories: $23 \%$ reported they decided based on financial reasons (e.g., it is 
affordable), 19\% said because of the location, $17 \%$ said they decided because of educational opportunities (e.g., academic program I wanted), $20 \%$ said family influenced their decision, $11 \%$ said friends influenced their decision, 5\% said the university was their first choice, and 5\% said the university was their backup school. Examples of responses that noted the influence of family and friends on the decision to attend are: "My mom and dad wanted me to go here," "My parents only want me to be in a university, not a community college," "I went to college and learned so much, and I know you will too," "My high school friend was going here so I wanted to as well," "I can't wait till we are in college together and in charge of our own lives."

Commitment to the Goal of Graduation. Students' initial commitment to the goal of graduation was measured at $\mathrm{T}_{1}(M=4.81$, $S D=.37)$, and subsequent commitment to the goal of graduation was measured at $\mathrm{T}_{2}$ $(M=4.64, S D=.56)$. Both variables were measured with a 3 -item scale $\left(\alpha_{\mathrm{T} 1}=.76\right.$, $\left.\mathrm{T} 2_{2}=.86\right)$ that included the following items: It is my goal to earn a 4-year college degree; Earning a college degree is important to me personally; Earning a college degree is important for my future success. Responses were based on a 5-point Likert scale ranging from 1 (strongly disagree) to 5 (strongly agree). These types of items have been used successfully in previous research assessing goal commitment in students' first-year experiences in college (e.g., Brower, 1992; Pascarella \& Terenzini, 1983).

Support From Family. Initial support from family for students goal of graduation was measured at $\mathrm{T}_{1}(M=4.60, S D=.51)$, and subsequent support from family for students' goal of graduation was measured at $\mathrm{T}_{2}(M=4.56, S D=.61)$. Both variables were measured with a 3 -item scale $\left(\alpha_{\mathrm{T} 1}=.68\right.$,
$\left.\alpha_{\mathrm{T} 2}=.81\right)$ that included the following items: My parent(s) want me to earn a college degree; My family is influential in my decision to pursue earning a college degree; Earning a college degree is important to my family. Responses were based on a 5-point Likert scale ranging from 1 (strongly disagree) to 5 (strongly agree).

Support From Friends. Initial support from friends for students' goal of graduation was measured at $\mathrm{T}_{1}(M=4.41, S D=.62)$, and subsequent support from friends for students' goal of graduation was measured at $\mathrm{T}_{2}(M=4.09, S D=.76)$. Both variables were measured with the following items: My close friends are or will work toward earning a college degree; Earning a college degree is important to my friends; My friends are influential in my decision to pursue earning a college degree. At T2, the last item was dropped in order to improve reliability assessments $\left(\alpha_{\mathrm{T} 1}=.74, \alpha_{\mathrm{T} 2}=.75\right)$. Responses were based on a 5-point Likert scale ranging from 1 (strongly disagree) to 5 (strongly agree).

Intention to Persist. Participants were asked at $\mathrm{T}_{2}$ to report on their expectations to persist at college $(M=4.26, S D=.70)$. Five items $(\alpha=.87)$ were used to assess expectations to persist in college: I expect to reenroll at this university in the Fall; I expect to reenroll at this university for my second year; I expect to do well my second year; I expect to complete the rest of my college career; I expect to do well the rest of my college career. Responses were based on a 5-point Likert scale ranging from 1 (strongly disagree) to 5 (strongly agree). Past studies have shown that intent measures of persistence strongly correlate with actual measures of persistence (see Cabrera et al., 1992) and scholars such as Berger and Braxton (1998) note that intent measures are "consistent with Tinto's emphasis on students' making a decision to depart" (p. 107). 


\section{STATISTICAL ANALYSIS}

Hierarchical regression was used to test all research questions. Hierarchical regression served as an appropriate statistical procedure because it allowed for variables to be entered into analysis in a theoretically meaningful manner. Control variables were included in all analyses so that the unique variance accounted for by variables under investigation could be interpreted meaningfully. To that end, Block 1 in every analysis herein consisted of control variables measured at $T_{1}$, these included whether the participant was a first-generation college student (dummy coded: $0=$ no, 1 =yes), high school GPA, parental income, parental financial college contribution, mother's education level, father's education level, and residence distance from school. Moreover, hierarchical regression was deemed a preferred procedure over advanced multivariate modeling techniques such as structural equation modeling because of the sample size that would have been required to simultaneously estimate every parameter in a model that included all of the variables measured in the present study. Said differently, structural equation modeling approaches generally call for a larger sample size than available here to have sufficient power (Holbert \& Stephenson, 2002). The hierarchical regression models analyzed here had adequate power and revealed theoretically meaningful relationships among the constructs under investigation.

Some additional considerations about these analyses are important to detail. First, missing values were handled by excluding cases pairwise due to the number of variables included in the analysis of a moderate sample size. Second, multicolinearity diagnostics were consistently examined; tolerance and variance inflation factor (VIF) values for all models indicated that the estimated variance was not erroneously inflated. Third, standardized regression coefficients are reported here to represent an effect size controlling for other variables.

\section{RESULTS}

The first research question assessed the degree to which initial relationship-specific support from family and friends impacted students' initial commitment to the goal of graduation. In order to assess these relationships, initial support from family and friends toward students' goal to graduate from college were classified as student entry characteristics. Variables were entered into two blocks: Block 1 consisted of control variables measured at $\mathrm{T}_{1}$ and Block 2 consisted of the independent variables of interest also measured at $T_{1}$ (initial support from family toward student's goal of graduation and initial support from friends toward student's goal of graduation). No control variables emerged as significant in Block 1. Results indicated that the overall the model was significant, $F(9,93)=5.30$, $p<.001$, in which the adjusted $R^{2}$ indicated that $29 \%$ of the variance was explained. Each of the independent variables of interest, initial support from family toward student's goal of graduation, $\beta=.46, t(93)=4.80$, $p<.001$, as well as initial support from friends toward students' goal of graduation, $\beta=.26, t(93)=2.81, p<.01$, significantly predicted students' initial commitment to the goal of graduation. See Table 1 for complete results of the hierarchical regression analysis used to address RQ1.

The second research question assessed to what degree subsequent relationship-specific support from family and friends impacted the student's subsequent commitment to the goal of graduation. Variables were entered into two blocks: Block 1 consisted of control variables that were measured at $T_{1}$ and 
Support and Persistence

TABLE 1.

Hierarchical Regression Results: Predicting Students' Initial Commitment to the Goal of Graduation (RQ1)

\begin{tabular}{|c|c|c|c|c|c|c|}
\hline Variable & $R^{2} / \mathrm{Adj} . R^{2}$ & $B$ & $S E B$ & $\beta$ & Tolerance & VIF $^{b}$ \\
\hline Block 1 & $.063 / .013$ & & & & & \\
\hline (Constant) & & 4.786 & .450 & & .627 & 1.595 \\
\hline First-Generation & & 0.036 & .099 & .048 & .623 & 1.605 \\
\hline Parental Income & & $-1.013 \mathrm{E}-7$ & .000 & -.012 & .935 & 1.070 \\
\hline High School GPA & & 0.064 & .111 & .062 & .563 & 1.775 \\
\hline Mother's Education & & -0.064 & .041 & -.215 & .573 & 1.746 \\
\hline Father's Education & & -0.003 & .041 & -.010 & .670 & 1.492 \\
\hline Parental Contribution & & 0.011 & .039 & .038 & .901 & 1.110 \\
\hline Distance From Campus & & -0.015 & .019 & -.089 & .627 & 1.595 \\
\hline Block 2 & $.362 / .294 * * *$ & & & & & \\
\hline (Constant) & & 2.899 & .481 & & & \\
\hline First-Generation & & 0.092 & .083 & .122 & .620 & 1.614 \\
\hline Parental Income & & $3.135 \mathrm{E}-8$ & .000 & .004 & .623 & 1.606 \\
\hline High School GPA & & -0.020 & .094 & -.019 & .916 & 1.092 \\
\hline Mother's Education & & -0.034 & .035 & -.115 & .552 & 1.812 \\
\hline Father's Education & & -0.005 & .034 & -.016 & .566 & 1.765 \\
\hline Parental Contribution & & -0.041 & .034 & -.135 & .614 & 1.627 \\
\hline Distance From Campus & & -0.016 & .016 & -.094 & .894 & 1.119 \\
\hline Initial Support From Friends ${ }^{a}$ & & 0.154 & .055 & $.257 * *$ & .908 & 1.102 \\
\hline Initial Support From Familya & & 0.332 & .069 & $.459 * * *$ & .831 & 1.204 \\
\hline
\end{tabular}

Block 2 consisted of the two independent variables of interest which were measured at $\mathrm{T}_{2}$ (subsequent support from family and subsequent support from friends toward a student's goal to graduate from college). Two control variables (first-generation and mother's education) emerged as significant in Block $1^{*}$, but were not significant in Block 2 .
Results indicated that overall the model was significant, $F(9,93)=15.04, p<.001$, in which the adjusted $R^{2}$ indicated that $58 \%$ of the variance was explained. One of the two independent variables of interest significantly predicted students' subsequent commitment to the goal of graduation. Subsequent support from family toward student's goal of graduation

* The impact of suppression between the measures of mother's education and first-generation status should be considered in the analysis of RQ2. Specifically, Darmawan \& Keeves (2006) describe cooperative suppression as occurring when "two predictors are negatively correlated with each other, but both are positively or (continues) 
revealed a large effect, $\beta=.72, t(93)=8.65$, $p<.001$, significantly predicting students' subsequent commitment to the goal of graduation. However, subsequent support from friends toward student's goal of graduation produced a much smaller result, $\beta=.04$, $t(93)=0.48, p=.63$, and was not a significant predictor of students' subsequent commitment to the goal of graduation. See Table 2 for the complete results of the hierarchical regression analysis for RQ2.

The third research question assessed to what degree subsequent commitment to the goal of graduation will significantly predict intention to persist in college. Variables were entered into three blocks: Block 1 consisted of control variables measured at $\mathrm{T}_{1}$, Block 2 consisted of two variables representing close others' support of a student's intention to persist (subsequent support from family toward the goal of graduation and subsequent support from friends toward the goal of graduation), and Block 3 included the independent variable of interest (student's subsequent commitment to the goal of graduation). Two control variables emerged as significant: mother's education was only significant in Block $1^{\dagger}$ whereas high school GPA remained significant in each block. Results indicated that overall the model was significant, $F(10,93)=6.14$, $p<.001$, in which the adjusted $R^{2}$ indicated that $36 \%$ of the variance was explained. Student's subsequent commitment to the goal of graduation was a significant and strong predictor of intention to persist, $\beta=.62$, $t(93)=4.61, p<.001$. Note the relationship between subsequent support from family and intention to persist appeared to be impacted by negative net suppression ${ }^{\ddagger}$ (Krus \& Wilkinson, 1986), although the effect was not significant. Table 3 documents the complete results of the regression analysis addressing RQ3.

* (continued) negatively correlated with Y. This is a case where each variable accounts for more of the variance in $Y$ when it is in an equation with the other than it does when it is presented alone" (p. 164). An empirical illustration of the presence of cooperative suppression is when the standardized regression coefficient $\left(\beta_{1}\right)$ exceeds the zero-order correlation between a variable and the outcome $\left(r_{Y 1}\right)$, and it has the same sign. This is certainly the case in the data here. The significant findings for mother's education and first-generation status in the analysis of RQ2 provide an example of cooperative suppression in Block 1. However, a reduction of the whole values of the standardized regression coefficients and the lack of significance for both variables in Block 2 reduce concern for cooperative suppression in the final model. Indeed, the tolerance and VIF estimates are not high enough for immediate concern (Cohen, West, Aiken, \& Cohen, 2003). Future research, which considers inclusion of alternate or additional variables in models like these should consider precautions for challenges presented by multicollinearity. Darmawan \& Keeves offer suggestions for analysis by modeling latent variables but these suggestions require larger data sets than presented here.

$\dagger$ Results for RQ3 provide another example of cooperative suppression involving mother's education and firstgeneration status with a similar pattern ensuing for the whole values of the standardized regression coefficients and the lack of significance for both variables in later blocks of the final model.

₹ Negative net suppression (Krus \& Wilkinson, 1986) impacted the results of the final model used to assess RQ3. This type of suppression occurs when a predictor variable has a regression weight with an opposite sign to its correlation with the criterion. For example here, subsequent support from family and intention to persist are positively correlated, $r(99)=.37, p<.01$. But, in the last block of the final model, subsequent support from family emerges as a negative predictor rather than a positive one, $\beta=-.25, t(93)=-1.76$, $p=n$.s. This occurs because the primary function of subsequent support from family is to suppress the error variance of subsequent commitment to the goal of graduation, rather than influencing substantially intent to persist. 


\section{DISCUSSION}

The first research question asked how initial relationship-specific support from family and friends impacts initial commitment to the goal of graduation. Results revealed that the initial support provided by both types of relationships has a significant impact on students' initial commitment to the goal of graduation. These results are coupled with the open-ended responses from participants about how they heard about the current university they are attending: $27 \%$ of respondents noted they heard about the school from family, and 9\% said they heard about the school from friends. When asked how they decided to attend college, $20 \%$ of participants noted that family influenced this decision while $11 \%$ noted that friends influenced their decision. As Cutrona et al. (1994) argue, the effects of social support from a parent or parents is probably a combination of the formative effects during development of interacting over time about the importance of getting a college degree. Students do not often hear one sole message about their parents' educational

TABLE 2.

Hierarchical Regression Results: Predicting Students' Subsequent Commitment to the Goal of Graduation (RQ2)

\begin{tabular}{|c|c|c|c|c|c|c|}
\hline Variable & $R^{2} / \mathrm{Adj} R^{2}$ & $B$ & $S E B$ & $\beta$ & Tolerance & VIF $^{b}$ \\
\hline Block 1 & $.176 / .109 *$ & & & & & \\
\hline (Constant) & & 4.756 & .593 & & & \\
\hline First-Generation & & -0.394 & .130 & $-.374 * *$ & .627 & 1.595 \\
\hline Parental Income & & $-8.003 E-7$ & .000 & -.065 & .623 & 1.605 \\
\hline High School GPA & & 0.190 & .147 & .131 & .935 & 1.070 \\
\hline Mother's Education & & -0.161 & .054 & $-.388 * *$ & .563 & 1.775 \\
\hline Father's Education & & 0.009 & .054 & .021 & .573 & 1.746 \\
\hline Parental Contribution & & -0.023 & .051 & -.054 & .670 & 1.492 \\
\hline Distance From Campus & & 0.020 & .025 & .081 & .901 & 1.110 \\
\hline Block 2 & $.617 / .576 * * *$ & & & & & \\
\hline (Constant) & & 2.273 & .487 & & & \\
\hline First-Generation & & -0.181 & .093 & -.172 & .590 & 1.695 \\
\hline Parental Income & & $-1.330 \mathrm{E}-6$ & .000 & -.108 & .615 & 1.625 \\
\hline High School GPA & & 0.001 & .103 & .001 & .901 & 1.109 \\
\hline Mother's Education & & -0.020 & .040 & -.048 & .490 & 2.039 \\
\hline Father's Education & & -0.036 & .038 & -.085 & .564 & 1.772 \\
\hline Parental Contribution & & -0.048 & .036 & -.114 & .655 & 1.527 \\
\hline Distance From Campus & & 0.006 & .018 & .025 & .842 & 1.188 \\
\hline Subsequent Support Fror & ends ${ }^{a}$ & 0.025 & .052 & .037 & .767 & 1.303 \\
\hline Subsequent Support Fror & mily ${ }^{a}$ & 0.608 & .070 & $.719 * * *$ & .660 & 1.515 \\
\hline
\end{tabular}

a Variables added in Block 2 are subsequent support from friends toward the goal of graduation and subsequent support from family toward the goal of graduation.

b VIF = variance inflation factor.

$* p<.05 . \quad * * p<.01 . \quad * * * p<.001$. 
TABLE 3.

Hierarchical Regression Results: Predicting Intention to Persist (RQ3)

\begin{tabular}{|c|c|c|c|c|c|c|}
\hline Variable & $R^{2} / \mathrm{Adj} R^{2}$ & $B$ & $S E B$ & $\beta$ & Tolerance & $\mathrm{VIF}^{\mathrm{C}}$ \\
\hline Block 1 & $.190 / .124 * *$ & & & & & \\
\hline (Constant) & & 2.750 & .795 & & & \\
\hline First-Generation & & -0.223 & .174 & -.157 & .627 & 1.595 \\
\hline Parental Income & & $1.573 \mathrm{E}-6$ & .000 & .094 & .623 & 1.605 \\
\hline High School GPA & & 0.633 & .196 & $.323 * *$ & .935 & 1.070 \\
\hline Mother's Education & & -0.184 & .073 & $-.327 *$ & .563 & 1.775 \\
\hline Father's Education & & -0.024 & .072 & -.043 & .573 & 1.746 \\
\hline Parental Contribution & & -0.024 & .068 & -.042 & .670 & 1.492 \\
\hline Distance From Campus & & 0.013 & .033 & .039 & .901 & 1.110 \\
\hline Block 2 & $.278 / .201 * *$ & & & & & \\
\hline (Constant) & & 1.213 & .903 & & & \\
\hline First-Generation & & -0.126 & .172 & -.089 & .590 & 1.695 \\
\hline Parental Income & & $9.898 \mathrm{E}-7$ & .000 & .059 & .615 & 1.625 \\
\hline High School GPA & & 0.541 & .191 & $.277 * *$ & .901 & 1.109 \\
\hline Mother's Education & & -0.112 & .075 & -.199 & .490 & 2.039 \\
\hline Father's Education & & -0.047 & .070 & -.083 & .564 & 1.772 \\
\hline Parental Contribution & & -0.024 & .066 & -.042 & .655 & 1.527 \\
\hline Distance From Campus & & 0.018 & .033 & .055 & .842 & 1.188 \\
\hline Subsequent Support From Friends ${ }^{a}$ & & 0.162 & .097 & .177 & .767 & 1.303 \\
\hline Subsequent Support From Familya & & 0.227 & .130 & .198 & .660 & 1.515 \\
\hline Block 3 & $.425 / .356 * * *$ & & & & & \\
\hline (Constant) & & -0.691 & .910 & & & \\
\hline First-Generation & & 0.025 & .158 & .018 & .564 & 1.772 \\
\hline Parental Income & & $2.104 \mathrm{E}-6$ & .000 & .126 & .604 & 1.656 \\
\hline High School GPA & & 0.540 & .171 & $.276 * *$ & .901 & 1.109 \\
\hline Mother's Education & & -0.096 & .067 & -.170 & .489 & 2.045 \\
\hline Father's Education & & -0.017 & .063 & -.031 & .558 & 1.791 \\
\hline Parental Contribution & & 0.017 & .060 & .029 & .641 & 1.561 \\
\hline Distance From Campus & & 0.013 & .030 & .039 & .840 & 1.190 \\
\hline Subsequent Support From Friends & & 0.141 & .087 & .154 & .765 & 1.307 \\
\hline Subsequent Support From Family & & -0.282 & .161 & -.247 & .349 & 2.864 \\
\hline Student's Subsequent Commitment to & Graduation $^{b}$ & 0.838 & .182 & $.620 * * *$ & .383 & 2.612 \\
\hline
\end{tabular}

a Variables added in block 2 are subsequent support from friends toward the goal of graduation and subsequent support from family toward the goal of graduation.

b Variable added in Block 3 is student's subsequent commitment to graduating.

c VIF = variance inflation factor.

$* p<.05 . \quad * * p<.01$. $* * * p<.001$. 
aspirations for them, but instead likely have been exposed to many messages about the importance, or unimportance, of school throughout their earlier years of schooling. A recent study assessing the impact of memorable messages from family about high school educational attainment found that $40 \%$ of the respondents reported hearing the message once in a while, $18 \%$ recalled hearing the message once a month, $24 \%$ recalled hearing the message every week, and $18 \%$ recalled hearing it on a daily basis (Strom \& Boster, 2011). Students hear messages about college choices and options from family and discuss such options, because parental opinion can be instrumental in life decisions like where to go to college and expectations for success in college. An example of how this discussion may occur was provided by one respondent, "Both parents attended college and we often talked about their experiences." Another respondent noted, "My mom always told me I would have an easier time getting a job with a college degree." Parental expectations for what happens after high school signal support that parents may or may not show for helping that student decide what to do and how to be successful after high school.

Similarly, our findings reveal that initial support from friends may impact decisions about school and degree attainment. Students notice what their friends are doing: if friends are dropping out. they may too, and conversely, if friends are going to college, they may decide to attend as well. This was evidenced in participants' responses about reaching the decision to go to this particular university, such as: "My friends and I always talked about going here" and "My friend and I would always talk about how we can't wait till we are in college together and in charge of our own lives." Thus the impact of similarity could be at play. Students who report higher goal commitment to getting a college degree may have more friends who share these goals, thereby strengthening their own commitment to graduating. It may be worthwhile to consider exploring the consequences (e.g., model fit, path relationships) of including initial support from close others like family and friends as student entry characteristics in future examinations of complete persistence models. Future assessments of complete persistence models with larger sample sizes and the inclusion of additional exogenous variables are needed to determine more specific implications for how initial support from close others should be integrated and analyzed.

The second research question asked how subsequent relationship-specific support (family and friends) impacts subsequent commitment to the goal of graduation. Results revealed that the subsequent support provided by family has a significant impact on students' subsequent commitment to the goal of graduation, while subsequent support from friends did not. Different mechanisms may be responsible for the link between outcomes predicted by parental support and those predicted by peer support. Work by Cutrona et al. (1994) found no effect of friend support on GPA in a sample of firstyear and second-year college students. Recent research by Thompson (2008) reveals that student academic support during the first year of college influenced academic performance where students believed they learned material more effectively when they worked with other students outside of the classroom setting. It is important to note that in Thompson's study students did not report that these were friends they were working with, but peers and classmates. New peer relationships might become more important throughout the first year of college, and support from such peers may replace support previously received from high school friends. A student's ability 
to make new connections may also explain the nonsignificant finding for subsequent support from friends in this study. Research by McEwan and Guerrero (2010) found that the perceived ability to initiate interaction emerged as a particularly important skill in the context of first-year students successfully integrating into a university; those who rated themselves as high in initiation skills at the beginning of the semester were more likely to report that they had used invitations, disclosure to others, responsiveness, and online social networking to form relationships during the early weeks of school. How students socially integrate is a key aspect of Tinto's persistence model and new peer relationships formed during the first year may become more important than prior friendships in terms of availability of support and impact on the goal to persist toward graduation. Overall, the findings here suggest that initial support from family and friends not only impacts students' goal to graduate as they enter college, but family support in particular continues to impact that goal throughout the first year of college.

Theories about how young adult transitions during this time period provide a context for understanding these findings. Theoretical work by Arnett (2010) advocates for viewing the 20s as a distinct life stage, which he calls "emerging adulthood," extending from (roughly) ages 18 to 25 . Among the cultural changes he points to that have led to "emerging adulthood" are the need for more education to survive in an information-based economy, fewer entrylevel jobs even after all that schooling, and young people feeling less rushed to marry. These cultural changes can result in young adults living longer in their parents' home and creating more opportunities to discuss future plans (e.g., graduating from college). Therefore, when considering the notion of emerging adulthood it may be that subsequent family support impacted the subsequent goal to graduate because students may have more exposure to parental support (e.g., advice) over longer periods of time when compared to exposure from the friends they had prior to college. In light of the changing expectations of students in emerging adulthood, parents may also be having more and longer impact on students' decisions as they move through college. Future investigations of complete models of student persistence may want to consider examining the effect of including subsequent family support as a factor affecting processes related to goal commitment, while also expanding the scope of this study by examining a larger scope of variables related to the institutional experience. Further, larger data sets should be incorporated to ensure that there is enough statistical power for advanced latent modeling techniques (for a review of techniques, see Darmawan \& Keeves, 2006).

The test of the third research question revealed that an individual's subsequent commitment to the goal of graduation was a significant predictor of intention to persist in college. As noted above, research incorporating goal commitment has produced mixed results when the impact of this construct has been previously tested in quantitative models. This finding provides further evidence that goal commitment is an important, and predictive, construct in the persistence puzzle. Yet, goal commitment is not the only piece of the puzzle that warrants attention. Understanding what drives goal commitment is also important to consider. With this study we continue work by Cabrera et al. (1993) to merge the aforementioned Tinto and Bean models of student persistence into a more integrated persistence model where relationship-specific support types (and not just global environmental factors as in Bean's model) are included as factors that affect goal commitment, and subsequently intent to persist. 


\section{Limitations}

The results of this study must be considered in the context of the limitations of the research. This study was conducted at a single institution, thus the findings of this study are not generalizable to every college institution. Also, only first-year students were assessed. Clearly, as evidenced from the findings for the second research question, subsequent support students receive from family impacts graduation goals throughout the first year of college, but certainly these could impact a student's entire college career. Thus, additional research should consider including students at different stages of their college career (e.g., transfer students) to determine if subsequent support from family has a different impact on graduation goals. Another characteristic of the sample to consider is many of the students included were first-generation college students, and there has been mixed findings on how firstgeneration status affects student persistence (e.g., Duggan, 2001; Somers, Woodhouse, \& Cofer, 2004). Using institutional data Ishitani (2003) discovered a higher risk of departure among first-generation students in their first year of college. Thus, having a sample with close to $40 \%$ of respondents reporting being first-generation college students adds important information to the research on persistence. As Pascarella and Terenzini (1998) note, finding inclusive and representative samples of highly diverse populations is and will continue to be difficult in studies on college student persistence. Yet, lack of communicated support from family and friends initially, and family subsequently, could affect how first-generation students view the importance of getting a college degree; because they are the first to go to college, these students may have to find other forms of support (e.g., peer support they gain while at college) that may affect their goal to reach graduation.

\section{Directions for Future Research}

This study is an initial attempt at understanding how different types of support from close others may affect commitment to the goal of graduating, and how the goal of graduating affects intention to persist. Initial support from family and friends and subsequent support from family do impact students' goal to proceed to graduation. Students do not enter college tabula rasa: new college students consider the educational influences of family and friends when starting college and rely on these supports to shape their own expectations for graduating from college. Additionally, family support was found to continue to influence goal commitment throughout the first year of college. As Cutrona et al. (1994) note, the effects of social support from a parent or parents is probably a combination of the formative effects during development of interacting over time about the importance of getting a college degree. Such interactions can happen over a long period of time and may be more ingrained and therefore longlasting for students even into "emerging adulthood" (Arnett, 2010).

Since Levin and Cureton (1998) reported that one in six undergraduates fits the traditional stereotype of the American college student-full-time, aged 18 to 22 , and living on campus- increasing numbers of institutions are striving to address this change by relying more on orientation programs, parent councils, help lines, and parent offices to define their relationship with families and keep families involved in students' college life (Daniel, Evans, \& Scott, 2001). The success of such initiatives is dependent on whether parents know of the existence of such resources. Consistent and multiple attempts at interactions among all primary caregivers, not just the most vocal, afford everyone the opportunity to participate in such experiences. 
Thus, future assessors of persistence models may want to include specific measurements of family involvement during the college experience to delineate the most effective forms of communication for including families in the process of student persistence.

\section{REFERENCES}

Argyle, M., \& Henderson, M. (1984). The rules of friendship. Journal of Social and Personal Relationships, 1, 211-237.

Arnett, J. J. (2010). Adolescence and emerging adulthood, 4th ed. Boston, MA: Prentice Hall.

Aseron, R. G., Sarason, I. G., \& Sarason, B. R. (1992). Social support and conflict: Global and relationship-specific aspects. Paper presented at the annual meeting of the American Psychological Association, Washington, DC.

Banks, B. J., Slavings, R. L., \& Biddle, B. J. (1990). Effects of peer, faculty, and parental influences on students' persistence. Sociology of Education, 63, 208-225.

Bean, J. P. (1980). Dropouts and turnover: The synthesis and test of a casual model of student attrition. Research in Higher Education, 12, 155-187.

Bean, J. P. (1982). Student attrition, intentions, and confidence: Interaction effects in a path model. Research in Higher Education, 17, 291-319.

Bean, J. P. (1983). The application of a model of turnover in work organizations to the student attrition process. Review of Higher Education, 6, 129-148.

Bean, J. P. (1985). Interaction effects based on class level in an exploratory model of college student dropout syndrome. American Educational Research Journal, 22, 35-64.

Berger, J. B., \& Braxton, J. M. (1998). Revising Tinto's interactionalist theory of student departure through theory elaboration: Examining the role of organizational attributes in the persistence process. Research in Higher Education, 39, 103-119.

Berger, J. B., \& Lyon, S. C. (2005). Past to present: A historical look at retention. In A. Seidman (Ed.), College student retention: Formula for student success (pgs. 1-29). Westport, CT: Prager.

Braxton, J. M. (2000). Reworking the student departure puzzle. Nashville, TN: Vanderbilt Press.

Braxton, J. M., \& Lee, S. D. (2005). Toward reliable knowledge about college student departure. In A. Seidman (Ed.), College student retention: Formula for student success (pp. 107-127). Westport, CT: Prager.

Braxton, J. M., \& McClendon, S. A. (2002). The fostering of social integration and retention through institutional practice. Journal of College Student Retention, 3, 57-71.

Braxton, J. M., Millem, J. F., \& Sullivan, A. S. (2000). The influence of active learning on the college student departure process: Toward a revision of Tinto's theory. Journal of Higher Education, 71, 569-590.

Braxton, J. M., Sullivan, A. S., \& Johnson, R. (1997). Appraising Tinto's theory of college student departure. In J. Smart (Ed.), Higher education: Handbook of theory and research (Vol. 12, pp. 107-164). New York, NY: Agathon.
Correspondence concerning this article should be addressed to Renee E. Strom, 117 Riverview, St. Cloud State University, 720 Fourth Avenue South, St. Cloud, MN 56301-4498; restrom@stcloudstate.edu

Brower, A. M. (1992). The second half of student integration: The effects of life task predominance on student persistence Journal of Higher Education, 63, 441-462.

Cabrera, A. F., Castaneda, M. B., Nora, A., \& Hengstler, D. (1992). The convergence between two theories of college persistence. Journal of Higher Education, 63, 143-164.

Cabrera, A. F., Nora, A., \& Castaneda, M. B. (1993). College persistence: Structural equations modeling test of an integrated model of student retention. Journal of Higher Education, 64, 123-139.

Cohen, J. (1960). A coefficient of agreement for nominal scales. Educational and Psychological Measurement, 20, 37-46.

Cohen, J., West, S. G., Aiken, L., \& Cohen, P. (2003) Applied multiple regression/correlation analysis for the behavioral sciences, 3rd ed. Mahwah, NJ.: Erlbaum Associates

Cole, J., Kennedy, M., Ben-Avie, M. (2009). The role of precollege data in assessing and understanding student engagement in college. New Directions for Institutional Research, 141, 55-69.

Cutrona, C. E. (1982). Transition to college: Loneliness and the process of social adjustment. In L. A. Peplau \& D. Perlman (Eds.), Loneliness: A sourcebook of current theory, research, and therapy (pp. 291-309). New York, NY: Wiley.

Cutrona, C. E., Cole, V., Colangelo, N., Assouline, S. G., \& Russell, D. W. (1994). Perceived parental social support and academic achievement: An attachment theory perspective. Journal of Personality and Social Psychology, 66, 369-378.

Daniel, B. V., Evans, S. G., \& Scott, B. R. (2001). Understanding family involvement in the college experience today. New Directions of Student Services, 94, 3-13.

Darmawan, I. G. N., \& Keeves, J. P. (2006). Suppressor variables and multilevel mixture modeling. International Education Journal, 7, 160-173.

DeBerard, M. S., Spielmans, G. I., \& Julka, D C. (2004). Predictors of academic achievement and retention among college freshmen: A longitudinal study. College Student Journal, 38, 66-80.

Demaray, M. K., \& Maleck, C. K. (2002). The relationship between perceived social support and maladjustment for students at risk. Psychology in the Schools, 39, 305-316.

Duggan, M. (2001, November). Factors influencing the first-year persistence of first-generation college students. Paper presented at the Annual Meeting of the Northeast Association for Institutional Research, Cambridge, MA.

Fan, X., \& Chen, M. (2001). Parental involvement and students' academic achievement: A meta-analysis. Educational Psychology Review, 13, 1-22. 
Holbert, R. L., \& Stephenson, M. T. (2002). Structural equation modeling in the communication sciences. Human Communication Research, 28, 531-551.

Hossler, D. (1984). Enrollment management. New York, NY: College Entrance Examination Board.

Ishitani, T. T. (2003). A longitudinal approach to assessing attrition behavior among first-generation students: Timevarying effects of precollege characteristics. Research in Higher Education, 44, 433-449.

Kenny, M. E., \& Rice, K. G. (1995). Attachment to parents and adjustment in late adolescent college students: Current status, applications, and future considerations. Counseling Psychologist, 23, 433-456.

Krus, D. J., \& Wilkinson, S. M. (1986). Demonstration of properties of a suppressor variable. Behavior Research Methods, Instruments, and Computers, 18, 21-24.

Lafreniere, K. D., \& Ledgerwood, D. M. (1997). Influences of leaving home, perceived family support, and gender on the transition to university. Guidance \& Counseling, 12, 14-18.

Levine, A., \& Cureton, J. S. (1998). When hope and fear collide: A portrait of today's college student. San Francisco, CA: Jossey-Bass.

MacGeorge, E. L., Samter, W., \& Gillihan, S. J. (2005). Academic stress, supportive communication, and health. Communication Education, 54, 365-372.

Mallinckrodt, B., \& Leong, F. T. (1992). Social support in academic programs and family environments: Sex differences and role conflicts for graduate students. Journal of Counseling and Development, 70, 716-723.

McEwan, B., \& Guerrero, L. K. (2010). Freshmen engagement through communication: Predicting friendship formation strategies and perceived availability of network resources from communication skills. Communication Studies, 61, 445-463.

Mortenson, S. T. (2006). Cultural differences and similarities in seeking social support as a response to academic failure: A comparison of American and Chinese college students. Communication Education, 55, 127-146.

Pascarella, E. T., \& Terenzini, P. T. (1983). Predicting voluntary freshman year persistence/withdrawal behavior in a residential university: A path analytic validation of Tinto's model. Journal of Educational Psychology, 75, 215-26.

Pascarella, E. T., \& Terenzini, P. T. (1991). How college affects students. San Francisco, CA: Jossey-Bass.

Pascarella, E. T., \& Terenzini, P. T. (1998). Studying college students in the 21st century: Meeting new challenges. Review of Higher Education, 21, 151-165.

Pascarella, E. T., \& Terenzini, P. T., \& Wolfe, L. M. (1986). Orientation to college freshman year persistence/withdrawal decisions. Journal of Higher Education, 57, 153-175.

Perry, S. R., Cabrera, A. F., \& Vogt, W. P. (1999) Career maturity and college student persistence. Journal of College Student Retention: Research, Theory, Practice, 1, 41-58.
Radford, A. W., Berkner, L., Wheeless, S. C., \& Shepherd, B. (2010). Persistence and attainment of 2003-04 Beginning postsecondary students: After six years (NCES 2011-151). Washington, DC: U. S. Department of Education.. Retrieved from National Center for Education Statistics website: http:// nces.ed.gov/pubsearch

Rausch, J. L., \& Hamilton, M. W. (2006). Goals and distractions: Explanations of early attrition from traditional university freshmen. Qualitative Report, 11, 317-334.

Rawlins, W. K. (1992). Friendship matters: Communication, dialectics and the life course. New York, NY: Aldine de Gruyter.

Somers, P., Woodhouse, S., \& Cofer, J. (2004). Pushing the boulder uphill: The persistence of first-generation college students. NASPA Journal, 41, 418-435.

Strom, R. E., \& Boster, F. J. (2007). Dropping out of high school: A meta-analysis assessing the effect of messages in the home and in school. Communication Education, 56, 433-452.

Strom, R. E., \& Boster, F. J. (2011). Dropping out of high school: Assessing the relationship between supportive messages from family and staying in school. Communication Reports, 24(1), 25-37.

Terenzini, P. T., Pascarella, E. T., Theophilides, C., \& Lorang, W. G. (1985). A replication of a path analytic validation of Tinto's theory of college student attrition. Review of Higher Education, 8, 319-340.

Thomas, S. L. (2000). Ties that bind: A social network approach to understanding student integration and persistence. Journal of Higher Education, 71, 591-615.

Thompson, B. (2008). How college freshmen communication student academic support: A grounded theory study. Communication Education, 57, 123-144.

Tinto, V. (1975). Dropout from higher education: A theoretical synthesis of recent research. Review of Educational Research, $45,89-125$.

Tinto, V. (1987). Theories of student departure revisited. In J. C. Smart (Ed.), Higher education: Handbook of theory and research, Vol. 2, pp. 359-384. New York, NY: Agathon.

Tinto, V. (1993). Leaving college: Rethinking the causes and cures of student attrition (2nd edition). Chicago, IL: University of Chicago Press.

Toor, R. (2000, October 6). Pushy parents and other tales of the admission game. Chronicle of Higher Education, p. B18.

Weinstock, J. S., \& Bond, L. A. (2000). Conceptions of conflict in close friendships and ways of knowing among young college women: A developmental perspective. Journal of Social and Personal Relationships, 17, 687-696.

Wofford, J., Goodwin, V., \& Premack, S. (1992). Metaanalysis of the antecedents of personal goal level and of the antecedents and consequences of goal commitment. Journal of Management, 18, 595-615. 